A RCHIWA, BIBLIOTEKI

I MUZEA KOŚCIELNE 91 (2009)

KS. WALDEMAR GRACZYK - WARSZAWA

\title{
ZACHOWANE SZCZĄTKI KSIĘGOZBIORÓW PO SKASOWANYCH W XIX WIEKU KLASZTORACH W DIECEZJI PLOCKIEJ W OBECNYCH ZBIORACH BIBLIOTEKI WYŻSZEGO SEMINARIUM DUCHOWNEGO W PLOCKU
}

Na polecenie Komisji Wyznań Religijnych i Oświecenia Publicznego w 1819 roku Samuel Bogumił Linde przybył na teren diecezji płockiej w celu ,zwizytowania" bibliotek po skasowanych klasztorach. W dniach od 25 do 28 maja 1819 roku, niestrudzony w swych działaniach Linde ,przejrzał” bibliotekę najstarszego na Mazowszu, klasztoru kanoników regularnych w Czerwińsku, paniem norbertanek w Płocku, księgozbiór kolegiaty płockiej oraz księgozbiór panien benedyktynek w Sierpcu. Dodatkowym ułatwieniem w pracy Samuela Bogumiła Lindego przy rewidowaniu bibliotek klasztornych na terenie diecezji płockiej, był fakt, iż Płock obok takich miejscowości jak Hebdów, Zawichost, Solec, Sieciechów, Włocławek i Sulejów n. Pilica, był również zaliczony do tzw. miast składnic dla zabranych przez Lindego książek z uwagi na jego położenie n. Wisłą, którą spławiano zapakowane w beczki i skrzynie stare księgozbiory do Warszawy.

Bibliotekę klasztoru kanoników regularnych w Czerwińsku zrewidował Linde w dniach od 25 do 27 maja 1819 r. skąd zabrał 1642 księgi, zapakowane w 59 pak, które spławiono Wisłą do składnicy Komisji Wojewódzkiej w Płocku. W swoich notatkach fakt ów skrupulatnie odnotował „Prawda, że wiele stąd biore jedynie dlatego, żeby ich nie zostawić na wieczną zgubę, lecz są i bardzo rzadkie i ważne np. Zwierciadło Mikołaja Reja, Hallera, Wietora, Szarffenbergera co niemiara..., inkunabułów i wydań pierwotnych bez liku". Z biblioteki czerwińskiej, Linde wywiózł do Warszawy również „rękopism pierwszej części Długosza". W tym samym czasie, rewizji dóbr podlegał także klasztor płocki panien norbertanek. Budynki poklasztorne norbertanek płockich zajęto w 1821 r. na użytek publiczny przeznaczając je dla potrzeb wojska (koszary wojskowe), same zaś zakonnice w liczbie 15 przeniesiono do potężnego klasztoru po kanonikach regularnych w Czerwińsku, gdzie przebywały wraz z pozostawionym w klasztorze proboszczem i służbą kościelną. Kościół bowiem po kasacie zamieniono na parafialny. Przy przeglądaniu w klasztorze płockich norbertanek Linde sumiennie odnotował ,[...] w Płocku u panien norbertanek zabrałem książek pak dziesięć, 
między innemi piękny egzemplarz pierwiastkowego wydania Biblii Wujka, Miaskowskiego Rytmów dobry, cały egzemplarz o co trudno [...] nadto Katechizm Marcina Białobrzeskiego, wydany w Krakowie w 1567 roku". Łącznie zabrał Linde 440 woluminów, które umieścił w dzieięciu pakach.

Dnia 28 V 1819 r. Linde odwiedził również klasztor panien benedyktynek w Sierpcu. Klasztor ten został wymieniony w dekrecie kasacyjnym z 17 IV 1819 r., nie został nigdy zamknięty a liczbę zakonnic zredukowano do połowy składu osobowego. Dekretem carskim 24 VII (10 VIII) 1824 r. wyłączono go spod supresji, przywracając wszelkie prawa własności i uposażenie do stanu jaki uprzednio posiadał. Benedyktynki sierpeckie przetrwały z uwagi na fakt prowadzenia szkoły dla dziewcząt. Z Sierpca zabrał Linde ,małą pakę książek polskich, najwięcej moralno-duchownych, zapakowawszy zleciłem burmistrzowi odesłanie jej do Płocka skąd razem z wielkim transporem wodnym dojdzie do Warszawy". Łącznie Linde zabrał z Sierpca 11 woluminów.

Na mocy tego samego dekretu z 17 IV 1819 r. uległo likwidacji w Królestwe Polskim 13 kolegiat w tym w województwie krakowskim: kapituła kolegiacka w Skalbmierzu, Wiślicy i Kurzelowie; województwie kaliskim w Choczu, Uniejowie, Sieradzu, Wieluniu, Łasku i Wolborzu; województwie lubelskim w Lublinie i Krasnymstawie; województwie mazowieckim w Łęczycy oraz województwie płockim - w Płocku. W każdej diecezji pozostawiono po jednej kolegiacie $\mathrm{z}$ uposażeniem dla proboszczów emerytów. W diecezji płockiej pozostawiono kolegiatę NMP w Pułtusku.

Skasowana kolegiata w Płocku pod wezwaniem św. Michała za zgodą Stolicy Apostolskiej, mocą reskryptu biskupa płockiego Andrzeja Załuskiego 4 X 1732 r. została przeniesiona do kościoła parafialnego pod wezwaniem św. Bartłomieja. Przy kolegiacie istniała biblioteka. Z wizytacji przeprowadzonej przez biskupa płockiego Michała Jerzego Poniatowskiego w 1775 r. dowiadujemy, że znajdowało się w niej 200 woluminów o tematyce biblijne, teologicznej, filozoficznej, prawniczej oraz dzieła klasyków łacińskich. Wizytator odnotował również istnienie dwóch kodeksów rękopiśmiennych Antyfonarza i Biblii. Nie dane było długo pozostać kolegiacie przy kościele św. Bartłomieja, bowiem za zgodą Stolicy Apostolskiej arcybiskup warszawski Franciszek Skarbek Malczewski,zniósł ją rozporządzeniem z dnia 30 III 1819 r. Wskutek tego biskup płocki Adam Michał Prażmowski 28 V 1819 r. wydał ordynację dla kościoła św. Bartłomieja w której potwierdził supremację kolegiaty płockiej, z zaznaczeniem, że zostaje ona kościołem parafialnym pod dozorem jednego z kanoników kapituły katedralnej z trzema wikariuszami.

Z Biblioteki zlikwidowanej kapituły kolegiackiej pw. św. Michała w Płocku przejął Linde w 1819 r. 122 książki. W ten sposób z terenu diecezji płockiej $\mathrm{z}$ trzech bibliotek klasztornych i jednej kolegiackiej przejęto w 1819 r. na rzecz Komisji Wyznań Religijnych i Oświecenia Publicznego łącznie 215 woluminów, nie licząc dubletów jak również cennych rękopisów.

Przeprowadzony pierwszy etap kasaty domów zakonnych w Królestwie Polskim miał na celu zlikwidowanie najlepiej uposażonych klasztorów. Tak zwana reforma klasztorów w Królestwie Polskim, zapoczątkowana przez Komisję 
Rządową zaraz po 1815 r. została dokończona przez władze carskie w lach 18641865 a celem jej była całkowita likwidacja życia zakonnego w Królestwie Polskim, w tym także w diecezji płockiej.

Druga fala likwidacji klasztorów na terenie diecezji płockiej miała miejsce w latach 1864-1865. Wówczas to na mocy ukazu carskiego Aleksandra II z dnia 27 X (8 XI) 1864 r., zlikwidowano wszystkie domy zakonne istniejące na terenie diecezji płockiej, ustalając ich status jako nieetatowy z nieprzekraczalną liczba ośmiu zakonników, właściwie skazanych na wymarcie m. in. z uwagi na zamknięcie nowicjatów i trudne warunki materialne. Były to klasztory: augustianów w Ciechanowie, benedyktynów w Pułtusku, bernardynów w Ostrołęce, Przasnyszu, Ratowie, Skępem i Strzegocinie, dominikanów w Płocku, franciszkanów konwentualnych w Dobrzyniu n. Wisłą, kapucynów w Zakroczymiu, karmelitów trzewiczkowych w Płońsku i Trutowie, misjonarzy w Płocku i Mławie, reformatów w Płocku, Pułtusku, Zarębach i Żurominie. Jako jedyny klasztor etatowy pozostawiono klasztor karmelitów trzewiczkowych w Oborach. Jedną z lepiej zaopatrzonych bibliotek klasztornych w diecezji płockiej była biblioteka bernardynów w Skępem. „Dobrodzieje klasztoru, szczególnie duchowni, zaopatrywali ją niekiedy w pozycje wyjątkowo cenne i nieodzowne dla kaznodziejów. Już fundator Mikołaj Kościelecki ofiarował najbardziej potrzebne księgi chórowe książki kaznodziejskie, a przełożony klasztoru bł. Władysław z Gielniowa wyjednał w pierwszych latach XVI wieku za pośrednictwem wpływowych braci książki od dobrodziejów. Na około 30 darowizn książkowych dla skępskiej biblioteki klasztornej, zanotowanych przez kronikarzy w latach 1529-1654, jedenaście pochodziło od duchowieństwa parafialnego i katedralnego, tyle samo od miejscowych bernardyńskich kaznodziejów i rezydentów, reszta od szlachty i mieszczan. Po likwidacji klasztoru w 1864 r. większa część zbiorów bibliotecznych znalazła się w bibliotece Seminarium Duchownego w Płocku".

Majątek po skasowanych klasztorach został przekazany dla potrzeb różnych instytucji państwowych (koszary wojskowe, lazarety, szkoły, szpitale, składy itd.). Zabudowania po reformatach w Płocku zostały przekazane Seminarium Duchownemu, które od 1867 r. znalazło tam swoją siedzibę. Staraniem administratora diecezji płockiej Wincentego Orzeszkowskiego, w 1870 r. zakończono akcję przewożenia ksiag do Seminarium Duchownego po skasowanych klasztorach w diecezji. Nie wiadomo dokładnie w jakiej ilości napłynęły księgi ze skasowanych klasztorów. Nie zachowały się bowiem żadne spisy.

Księgozbiór ten wiosną 1941 r. okupant niemiecki załadował do skrzyń, po czym wywiózł do Sierpca a stamtąd koleją do Królewca. W niemieckiej gazecie wydawanej w Płocku Plocker Tageblatt pod datą 26 sierpnia 1941 r. napisano, że księgozbiór płocki, liczący 50 tys. tomów, w tym 100 rękopisów i ponad 300 inkunabułów, został przewieziony do Państwowej i Uniwersyteckiej Biblioteki w Królewcu. Kradzież księgozbioru nazwano „porządkowaniem bibliotek w Południowych Prusach”, a Płock „,miejscem odkrycia starych dokumentów kultury niemieckiej”. W Królewcu zbiory Biblioteki i Archiwum znajdowały się do zakończenia wojny w 1945 r. Zaledwie szczątki tego księgozbioru przedwojennego powróciły na swoje dawne miejsce do Biblioteki Seminarium Duchownego. 
W chwili obecnej w zasobie starych druków odotowujemy obecność ksiąg po następujących zakonach a w ich obrębie klasztorach, z druków XVI -wiecznych: benedyktyni w Płocku - trzy woluminy, benedyktyni w Pułtusku - jeden wolumin, bernardyni z Przasnysza - dwa woluminy, po jednym woluminie misjonarze z Płocka i Mławy, jezuici z Płocka oraz karmelici trzewiczkowi z Obór (klasztor nie uległ kasacie, funkcjonował jako etatowy. Zbiory jego uległy znacznemu rozproszeniu). Nie zabrakło równiez ksiąg $\mathrm{z}$ dawnego opactwa kanoników regularnych z Czerwińska i jego prepozytur: Krasnego - 13 woluminów i Pomiechowa - dwa.

Spośród druków XVII -wiecznych w obecnych zbiorach znajdują się księgi z następujących zakonów: benedyktyni z Płcka - trzy woluminy, po jednym woluminie: bernardyni z Przasnysza i Skępego. Stosunkowo duża liczba ksiag pochodzi z opactwa kanoników regularnych z Czerwińska $n$. Wisłą i jego prepozytur (łącznie 23 woluminy) z tego z Czerwińska - dziesięć, z prepozytury w Krasnem - osiem, z prepozutury w Błoniu - trzy, po jednym z prepozytury w Pomiechowie i św. Jerzego w Warszawie, misjonarze z Płocka - dwa woluminy.

I z XVIII -wiecznych druków: benedyktyni z Płocka - trzy woluminy, benedyktyni z Pułtuska - 11 woluminów, bernardynie ze Skępego - cztery, po jednym woluminie: dominikanie w Płocku, franciszkanie w Wyszogrodzie, kapucyni w Zakroczymiu, misjonarze w Pułtusku, reformaci w Ratowie, reformaci w Żurominie, reformaci w Zarębach, reformaci w Płocku, reformaci z Pułtuska, norbertanki z Płocka; kanonicy regularni z Czerwińska - 7 woluminów, prepozytura kanoników regularnych w Krasnem - cztery woluminy, prepozytura kanoników regularnych w Błoniu - jeden wolumin, misjonarze z Płocka - 16 woluminów, misjonarze z Mławy - pięć. 